Nie będę dalej pastwił się nad autorką, której praca obnażyła braki na każdym polu kompetencji. Przyznam, że już dawno nie czytałem tak złej książki. Mam nawet wątpliwości, czy recenzentka, która wydała (jak mniemam) pozytywną o niej opinię, w rzeczywistości czytała ten tekst. Czyż można było bowiem nie zauważyć, że autorka te same partie tekstu przywołuje po kilka razy w różnych miejscach książki (takie powtórzenia znajdziemy np. na s. 94 i 99 [przypis nr 37]; na s. 34 i 100, na s. 136 i 191 etc.)? Czy można było przeoczyć, że praca jest niespójna i źle skonstruowana? Czy jest możliwe, aby po przeczytaniu tekstu, nie zauważyć aż tylu w nim sprzeczności?

Kończąc, raz jeszcze zacytuję autorkę recenzowanej publikacji. Pod koniec swoich rozważań Jodłowska stwierdza: „Dzisiejsza pedagogika jest nijaka. Ciągle niewiele liczy się wśród innych nauk. Ma niewielki dorobek teoretyczny. I nie jest to bolączka polskiej pedagogiki. Dlaczego tak jest?” (s. 245). No właśnie: dlaczego?

Mariusz Menz (Poznań)

\title{
Próba adaptacji idei regionalistycznej do edukacji szkolnej. Recenzja publikacji Danuty Konieczka-Śliwińskiej pt: Edukacyjny nurt regionalizmu w Polsce po 1918 roku. Konteksty - koncepcje progra- mowe - realia, Wydawnictwo Instytutu Historii UAM, Poznań 2011, ss. 502
}

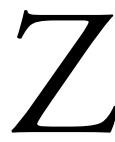

asadniczym warunkiem realizacji edukacji regionalnej jest świadomość społeczeństwa, a zwłaszcza władz oświatowych i nauczycieli. Istnieje potrzeba prowadzenia takiej edukacji, wobec postępujących procesów globalizacji, uniwersalizacji, co wiąże się także z unifikacją w dziedzinie oświaty i kultury. Tu szczególnie ważne staje się zachowanie tożsamości narodowej, a ta jest związana z ojczyzną najpierw prywatną, potem regionalną, dalej ogólnonarodową, a wreszcie ogólnoludzką. Odwoływanie się w procesie edukacji do wspólnoty miejsca urodzenia, tradycji daje szansę zachowania ciąłości ogólnonarodowej, a także europejskiej wspólnoty, której jesteśmy członkami.

W tym kontekście zagadnienia związane z regionem mieszczą się w kręgu zainteresowań badaczy wielu dziedzin nauki, ale też różnych instytucji i organizacji. 
To właśnie poczucie przynależności do konkretnego miejsca, właściwa człowiekowi potrzeba zakorzenienia, pozwala odnaleźć się młodemu człowiekowi we współczesnym świecie, zrozumieć kim jest i czuć się bezpieczniej.

Problematyka związana $\mathrm{z}$ wykorzystaniem dziejów regionalnych w edukacji stanowi obecnie, podobnie jak w przeszłości, jedno z ważnych zagadnień w badaniach naukowych oraz w szeroko rozumianej popularyzacji wiedzy o przeszłości. Kwestie współzależności między rozwojem człowieka a jego środowiskiem zrodziły się już w XIX wieku, warto o tym pamiętać mając na uwadze kontekst wzbogacania wiedzy o kulturze miejsca zamieszkania. Dysponujemy aktualnie sporym już dorobkiem w tym zakresie, są to jednak publikacje najczęściej przyczynkarskie o różnym charakterze. Regionalizm to również ważny, choć nie jedyny obszar badawczy Danuty Konieczki-Śliwińskiej. Wyrazem tych zainteresowań są opracowania związane bezpośrednio z dziejami regionów: kujawskiego i wielkopolskiego, a także prezentujące region w szerszej przestrzeni historycznej, czego wymiernym przykładem jest recenzowana książka. Książka Danuty Konieczki-Śliwińskiej jest pełną i dogłębną syntezą jednego z głównych nurtów regionalizmu historycznego w Polsce, rozpatrywanego w trzech przestrzeniach czasowych: lat międzywojennych (1918-1939), okres po II wojnie światowej (1944-1989) oraz czasów współczesnych (1989-2009).

Ze względu na rozległość problematyki i interdyscyplinarny charakter materiałów źródłowych autorka skoncentrowała swoje badania na edukacyjnym nurcie szerszego zjawiska regionalizmu historycznego od momentu odzyskania niepodległości przez Polskę w 1918 r. Cezurę początkową wyznaczył fakt, że idee regionalistyczne w edukacji najpełniej odzwierciedlają się w koncepcjach programowych zatwierdzonych do użytku szkolnego, z czym mieliśmy do czynienia w II RP. Cezurę końcową badań stanowił rok 2009, kiedy to Ministerstwo Edukacji Narodowej wprowadziło nową reformę programową, stanowiącą również o zmianie statusu edukacji regionalnej.

Opracowanie wpisuje się w interdyscyplinarną refleksję nad problematyką regionalizmu i edukacji regionalnej. Autorka daje temu wyraz i w pewnych aspektach odwołuje się do dorobku takich dyscyplin naukowych, jak: geografia, socjologia, psychologia, pedagogika. Oczywiście w zasadniczym postępowaniu koncentruje się na historycznej perspektywie badawczej.

Wymienione wyżej aspekty znalazły pełne odzwierciedlenie nie tylko w tytule pracy, ale także w jej strukturze. Licząca 502 strony pozycja składa się z obszernego wprowadzenia, trzech głównych części, z których każda zawiera po parę rozdziałów oraz z bogatej interdyscyplinarnej bibliografii. Przedmiotem analiz jest pojęcie nurtu edukacyjnego $\mathrm{w}$ regionalizmie historycznym w odniesieniu do placówek szkolnych o charakterze podstawowym i ponad podstawowym. Warto przy 
tym podkreślić nowatorską konstrukcję książki, jej główne wątki to Konteksty, Koncepcje programowe i Realia.

We wstępie, określonym jako wprowadzenie, Autorka przedstawiła uzasadnienie wyboru tematu, zwłaszcza jego aspekt związany z budową polskiego społeczeństwa obywatelskiego, w którym kształtują się różne instytucje, organizacje stanowiące o aktywności i uczestniczeniu w życiu społecznym, także przez młodzież. Ten człon książki zawiera także prezentację bazy źródłowej, stanowią ją w bardzo szerokim zakresie wykorzystane programy nauczania historii i edukacji regionalnej dla wszystkich typów szkół, instrukcje programowe i podręcznikowe, sprawozdania dyrekcji szkół, podręczniki szkolne i materiały dydaktyczne z historii i edukacji regionalnej, oraz dokumenty wielu organów zarządzających oświatą, zarówno centralnych, jak i wielu terenowych, oraz literaturę przedmiotu, polską i obcą.

Całość problematyki została zaplanowana $\mathrm{w}$ dwóch równoległych porządkach prezentacji: historycznym, pozwalającym prześledzić dzieje adaptacji idei regionalistycznej do edukacji szkolnej w trzech kolejnych etapach rozwoju polskiego systemu oświaty, oraz genetyczno-praktycznym, ukazującym przemiany konkretnych koncepcji programowych przez pryzmat rozległych czynników je warunkujących i przejawów realizacji tych koncepcji w praktyce. We wstępie odniosła się także Autorka do podstawowych pojęć, odgrywających kluczową rolę w badaniach nad adaptacją idei regionalistycznej w edukacji szkolnej, w tym szczególnie odnosząc się do tytułowego określenia: regionalizmu historycznego. Warto by przy tym, jak sądzę, dla uzupełnienia szerszej płaszczyzny widzenia problemu wyjaśnić także rozumienie pojęcia edukacji i jej rodzajów.

Część pierwsza monografii bardzo trafnie i obrazowo zatytułowana Konteksty przybliża genezę, dzieje i organizację ruchu regionalistycznego w Polsce. Rozdziały pierwszy i drugi tej części książki przynoszą próbę uściślenia pojęć związanych z tytułową problematyką, trafnie przy tym dbając o ład i przejrzystość wobec nadrzędnych ustaleń. Rozdział trzeci, zgodnie z tytułem, przynosi prezentację rozwoju regionalizmu w edukacji szkolnej, uwarunkowania, inspiracje i obszary adaptacji. W sposób wyraźny został wyeksponowany związek przeszłości ze współczesnością, rozwój regionalizmu na tle przemian myśli psychologiczno-pedagogicznej XX wieku, wskazując na jego rolę we współczesnych koncepcjach edukacyjnych. Swą uwagę skoncentrowała Autorka zasadniczo na nauczaniu szkolnym pomijając edukację pozaszkolną i źródła wiedzy związane z tradycją rodzinną i kulturową. Takie postępowanie, jak zastrzega we wstępie, nie było wprawdzie jej zamiarem, ale zapewne przyczyniłoby się do dokładniejszego usystematyzowania badanych zagadnień. Zważywszy przy tym, że jedną z przyczyn niskiego stanu wiedzy uczniów o swoim regionie jest współdziałanie nauczycieli z rodziną i najbliższym środowiskiem (Potwierdzam w tym względzie wyniki badań M. Chen-Wincławskiej, patrz s. 408- 
-410 recenzowanej książki, nie budzą mojego zaskoczenia, ponieważ, prowadząc badania w latach 1985-1995 na Śląsku Opolskim, uzyskałam podobne wyniki).

Trafnej analizie i ocenie poddano takie zagadnienia, jak: edukacja wielokulturowa i międzykulturowa, edukacja środowiska i ekologiczna, edukacja kulturalna i edukacja kulturowa oraz edukacja regionalna i regionalizacja nauczania. Poruszane kwestie koncentrowały się zarówno wokół ogólnych, teoretycznych rozważań, pomiędzy teorią i praktyką, jak też analizą konkretnych zastosowań teorii w praktyce. Może w tym ostatnim zakresie zabrakło rozważań na tle szerszego europejskiego kontekstu, mimo że zgodnie z tytułem książka odnosi się do regionalizmu historycznego w Polsce. Europejski wymiar edukacji powinien być postrzegany przez pryzmat edukacji regionalnej i międzykulturowej. W tym zakresie aktualnie wymagany jest wzrost kompetencji nauczycielskich i doskonalenia zawodowego tego obszaru. Edukację regionalną należy wiązać z edukacją europejską z jej korzeniami i źródłami. Mając na uwadze potrzebę kształtowania poczucia przynależności do europejskiego kręgu kulturowego istnieje potrzeba zrozumienia i odczucia tego, co wspólne dla wielu krajów, pomimo wszelkich odrębności składających się na tożsamość etniczną i regionalną. Warto poszukiwać takich ujęć, które pozwalałyby na dostrzeganie zmieniającej się perspektywy i charakteru kontaktów kulturowych na przestrzeni historii europejskiej. Nowy model kształcenia wśród wielu założeń i dążeń powinien charakteryzować się wprowadzeniem uczniów w dziedzictwo kultury lokalnej, regionalnej, narodowej, a także europejskiej i światowej.

Tę część publikacji zamyka rozdział czwarty stanowiący przegląd opinii polskiego środowiska historyczno-dydaktycznego na temat roli regionalizmu historycznego w edukacji szkolnej. Formułowane poglądy prezentowane są w ujęciu chronologicznym, dotyczą różnych lat i różnych uwarunkowań społeczno-politycznych, co warto z uznaniem odnotować.

Część druga recenzowanej pozycji zatytułowana Koncepcje programowe zawiera wnikliwą analizę programów nauczania funkcjonujących w naszych dziejach na przestrzeni XX wieku w latach 1918-2009. Autorka zwraca uwagę, że pozostawały one bardzo często pod presją wydarzeń politycznych i to nie tylko w okresie PRL-u. $\mathrm{Na}$ podstawie analizy wielu programów nauczania, wyodrębniania najbardziej wartościowych doświadczeń, wspólnych cech, uzyskiwaliśmy obraz swoistego modelu związanego z przeprowadzanymi reformami edukacyjnymi w różnych okresach naszych dziejów. Bogata podstawa źródłowa tej części książki przynosi ważny dla współczesnej praktyki przegląd reform edukacyjnych i w tym względzie spotkać się powinna z dużym zainteresowaniem teoretyków i praktyków oświaty nie tylko w kraju, ale i za granicą. Nie chodzi tu oczywiście o mechaniczne przenoszenie wzorów rozwiązań strukturalnych, sposobu prezentacji, ale o twórcze spożytkowanie badań prowadzonych zgodnie z regułami warsztatu naukowego historyka. 
Na podstawie analizy najbardziej ważnych i wartościowych doświadczeń i dokumentów wyodrębniona została trzecia część książki Realia. Mamy okazję prześledzić tu procesy realizacji koncepcji regionalizmu historycznego w trzech wyodrębnionych tytułami okresach czasowych.

Po wszechstronnej analizie prawidłowości w sposobie i zakresie tematyki regionalnej w szkolnej edukacji Autorka dostrzega i wyróżnia problemy związane z możliwościami bezpośredniej transmisji regionalizmu w praktyce szkolnej. Dostrzega w końcowych wnioskach, że wprowadzenie tematyki regionalnej do programów nauczania przynosi wyraźne korzyści w zakresie wiedzy i kształtowania pożądanych postaw ucznia. Taką ocenę umożliwia przeprowadzona analiza porównawcza sposobów wdrażania określonej koncepcji regionalizmu w różnych okresach naszych dziejów i przeprowadzonych w tym czasie reform nauczania.

Jak na profesjonalnego historyka i dydaktyka przystało, Danutę Konieczkę-Śliwińską interesują procesy wskazujące na sposoby docierania do czytelnika, obok tych tradycyjnych opracowań metodycznych dotyczących bezpośrednio edukacji regionalnej - mamy także do czynienia z nową formą przekazywania informacji dla nauczycieli poprzez dostęp do internetu. Dzięki temu nauczyciele uzyskują szeroki i wielowątkowy obszar prezentacji przykładów realizacji edukacji regionalnej.

W obszernym podsumowaniu Autorka dokonuje zwięzłej rekapitulacji celu badań, charakteru refleksji metodologicznej i sposobu prezentacji swoich ustaleń. Tę ostatnią kwestię można uznać za niezwykle ważną a zarazem oryginalną.

Publikację zamyka wykaz wykorzystanych w pracy źródeł oraz bardzo obszerna interdyscyplinarna bibliografia. W sposobie jej prezentowania trafnie przyjęto układ chronologiczno-alfabetyczny i alfabetyczny. Na uznanie zasługuje staranne wydanie książki, jej szata graficzna, a także jasna i przejrzysta struktura oraz komunikatywny język.

Kończąc, warto podkreślić, że recenzowana książka Danuty Konieczki-Śliwińskiej Edukacyjny nurt regionalizmu historycznego w Polsce po 1918 roku. Konteksty - koncepcje programowe - realia stanowi wartościową, pogłębioną i całościową syntezę jednego z głównych nurtów regionalizmu w Polsce. Wskazane byłoby, aby ta cenna publikacja znalazła się w wielu naszych bibliotekach, była dostępna szerszemu ogółowi czytelników, zwłaszcza nauczycieli i pracowników oświaty nie tylko w Polsce, ale i wielu innych krajach. W rezultacie można sądzić, że książka skłoni odbiorcę do refleksji, wzbogaci sposoby działania w praktyce, a tym samym można mieć nadzieję, że nasza edukacja szkolna zmieniać się będzie na lepsze. 